\title{
Inheritance of Compact Growth Habit, and Investigation of Linkage to Weeping Architecture and Purple Leaf Color in Eastern Redbud (Cercis canadensis L.)
}

\author{
Hsuan Chen and Dennis J. Werner \\ Department of Horticultural Science, North Carolina State University, Raleigh, \\ NC 27695
}

\section{Additional index words. ornamental plant, Fabaceae, tree genetics, dwarf growth}

\begin{abstract}
Eastern redbud (Cercis canadensis L.) is a commonly used small landscape tree. Compact growth, purple leaf color, and weeping architecture are three popular ornamental phenotypes. Inheritances of weeping architecture and purple leaves have been reported previously. Inheritance of compact growth habit and its genetic linkage with the weeping and purple leaf genes have not been reported. In the present research, the inheritance of compact growth derived from 'Ace of Hearts' was explored in the $F_{1}, F_{2}$, and reciprocal backcross families resulting from the controlled hybridization of 'Ruby Falls' (normal growth/weeping architecture/purple leaf) $\times$ 'Ace of Hearts' (compact growth/nonweeping architecture/green leaf). All $27 \mathrm{~F}_{1}$ individuals were nonweeping, green-leaved, and noncompact. A total of $572 \mathrm{~F}_{2}$ progeny were obtained, and subsequent analysis of segregation revealed a single recessive gene controlled compact growth habit. Analysis of reciprocal backcross families confirmed this result as well. Weeping architecture and purple leaf color were also controlled by single recessive genes, confirming findings presented in previous studies in another redbud family. No linkage between the three genes was detected. This research is the first to report the inheritance of compact growth in eastern redbud and confirms independent assortment between the compact, purple leaf, and weeping genes.
\end{abstract}

Eastern redbud (Cercis canadensis L.) is a popular small landscape tree. In the two most recent U.S. Department of Agriculture (USDA) Censuses of Horticultural Specialties, redbud was the fifth most valuable deciduous flowering tree in the United States. As reported in the USDA Censuses of Horticultural Specialties, economic value of redbuds increased from $\approx 21.8$ million in 2009 to 28.4 million in 2019 (USDA-NASS, 2009; USDA-NASS，2015; USDA-NASS, 2020). Eastern redbud is widely used in landscaping because of its moderate size and wide adaptability (Werner and Snelling, 2010). Mature redbud can range from small shrubs to medium trees, grow in full sun to shade, and are hardy from USDA zones 4 to 9 (Kidwell-Slak and Pooler, 2018; Raulston, 1990). Their showy early spring flowers and heart-shaped foliage also contribute to their popularity (Kidwell-Slak and Pooler, 2018).

Diverse morphologies in eastern redbud have been used in breeding for increasing their ornamental value and diversifying

Received for publication 7 June 2021. Accepted for publication 8 Sept. 2021.

Published online 29 October 2021.

H.C. is an Assistant Professor.

D.J.W. is a Distinguished Professor Emeritus.

D.J.W. is the corresponding author. E-mail: djw@ncsu.edu.

This is an open access article distributed under the CC BY-NC-ND license (https://creativecommons. org/licenses/by-nc-nd/4.0/). landscaping utility (Roberts et al., 2015). Popular traits like leaf color mutations (purple, gold, variegated), double flowers, compact growth, and weeping architecture are found in many current cultivars (Kidwell-Slak and Pooler, 2018). The inheritance and allelism of many of these popular traits have been studied (Roberts et al., 2015). For example, Roberts et al. (2015) demonstrated that purple leaves of 'Ruby Falls', 'Forest Pansy', and 'Greswan' were all controlled by the same recessive allele $(p l l)$. Two nonallelic weeping genes were reported; the weeping gene of 'Covey' and 'Ruby Falls' (wpl), and the weeping gene of 'Traveller' $(C$. canadensis var. texensis) (Roberts et al., 2015).

Compact redbud cultivars are popular in the market because of their ability to fill specific landscape niches (Fantz and Woody, 2005). 'Ace of Hearts' and 'Little Woody' are nonweeping, compact cultivars released in 2005 that were selected from a bulked seed population that originated from Morganton Nursery (Morganton, NC) and do not have clear pedigrees (Fantz and Woody, 2005). 'Ace of Hearts' is a popular compact cultivar with a dome-shaped canopy and small, heartshaped leaves (Fantz and Woody, 2005). Although its unique compact form is a valuable ornamental trait, the inheritance of compact growth habit is unclear. Understanding its inheritance will assist breeders using the compact trait in future breeding efforts.

In this research, hybrid families, including $\mathrm{F}_{1}, \mathrm{~F}_{2}$, and reciprocal backcross families of
'Ruby Falls' (noncompact/weeping architecture/purple leaf) $\times$ 'Ace of Hearts' (compact/ nonweeping architecture/green leaf) were created and used to 1) study the inheritance of the compact trait derived from 'Ace of Hearts', and 2) investigate linkage relationships between the genes controlling compactness, weeping, and purple leaves.

\section{Materials and Methods}

Plant material. Inheritances of the three traits were explored in $\mathrm{F}_{1}, \mathrm{~F}_{2}, \mathrm{BC}_{1 \mathrm{P} 1}$, and $\mathrm{BC}_{1 \mathrm{P} 2}$ families derived from hybridization of C. canadensis 'Ruby Falls' (noncompact/ weeping architecture/purple leaf) $\times$ 'Ace of Hearts' (compact/nonweeping architecture/ green leaf). 'Ruby Falls' was released in 2009 (Werner and Snelling, 2010). 'Ruby Falls' carries the recessive weeping gene ( $w p 1 w p 1)$ and the recessive purple gene $(p l l p l 1)$ derived from $C$. canadensis 'Forest Pansy' (USPP 2556), a purple-leaved redbud discovered in 1947 by Forest Nursery, McMinnville, TN (Dirr, 2009). 'Ace of Hearts' is a compact cultivar with small, glossy, heart-shaped leaves introduced in 2005 (Fantz and Woody, 2005).

Hybridizations of potted parental plants were conducted in the North Carolina State University Horticulture Field Laboratory greenhouse in Raleigh, NC, in 2011. Modified seed scarification treatment was used (Banner and Stein, 2008). Harvested seed was sown after acid scarification treatment and 2-month cold stratification at $4{ }^{\circ} \mathrm{C}$. For acid scarification, seed was submerged in concentrated $(18.4 \mathrm{M})$ sulfuric acid for $30 \mathrm{~min}$. Seed was gently stirred briefly every $2 \mathrm{~min}$ for the first $10 \mathrm{~min}$, and at 5-min intervals thereafter. Acid-scarified seed was then rinsed and cold stratified for $\approx 2$ months. A total of $27 \mathrm{~F}_{1}$ plants were ultimately recovered. $\mathrm{F}_{1}$ plants were grown in the greenhouse in 2011 until being transplanted into a field isolation block in Winter 2012 at the Sandhills Research Station, Jackson Springs, NC.

To create the $F_{2}$ family, one $F_{1}$ tree was dug from the field, planted in a $95-\mathrm{L}$ pot, and brought to the greenhouse for crossing. In Mar. 2015, branches containing flower buds were cut from multiple $F_{1}$ trees in the field and brought to the greenhouse for flowering. Mixed pollen from the cut branches was bulked and used to pollinate the single $\mathrm{F}_{1}$ tree. $F_{2}$ seed was harvested in Fall 2015, and acid scarified and cold stratified before being sown in January 2016. Resultant seedlings were grown in the greenhouse in individual pots to a height of $\approx 15 \mathrm{~cm}$ and transplanted to the field in May 2016 at the Sandhills Research Station. Trees were evaluated for leaf color, weeping/nonweeping, and compact/noncompact characteristics in Oct. 2016 (Fig. 1).

Hybridizations to create backcross families $\mathrm{BC}_{1 \mathrm{P} 1}$ and $\mathrm{BC}_{1 \mathrm{P} 2}$ were conducted in Mar. 2017. To create the $\mathrm{BC}_{1 \mathrm{P} 1}$ family, bulked pollen from two $F_{1}$ individuals was used to pollinate one 'Ruby Falls' tree in the greenhouse. To create the $\mathrm{BC}_{1 \mathrm{P} 2}$ family, pollen of 'Ace of Hearts' was used to pollinate one $\mathrm{F}_{1}$ individual in the same greenhouse. $\mathrm{BC}_{1 \mathrm{P} 1}$ and $\mathrm{BC}_{1 \mathrm{P} 2}$ seeds were harvested in Sept. 2017, scarified and 

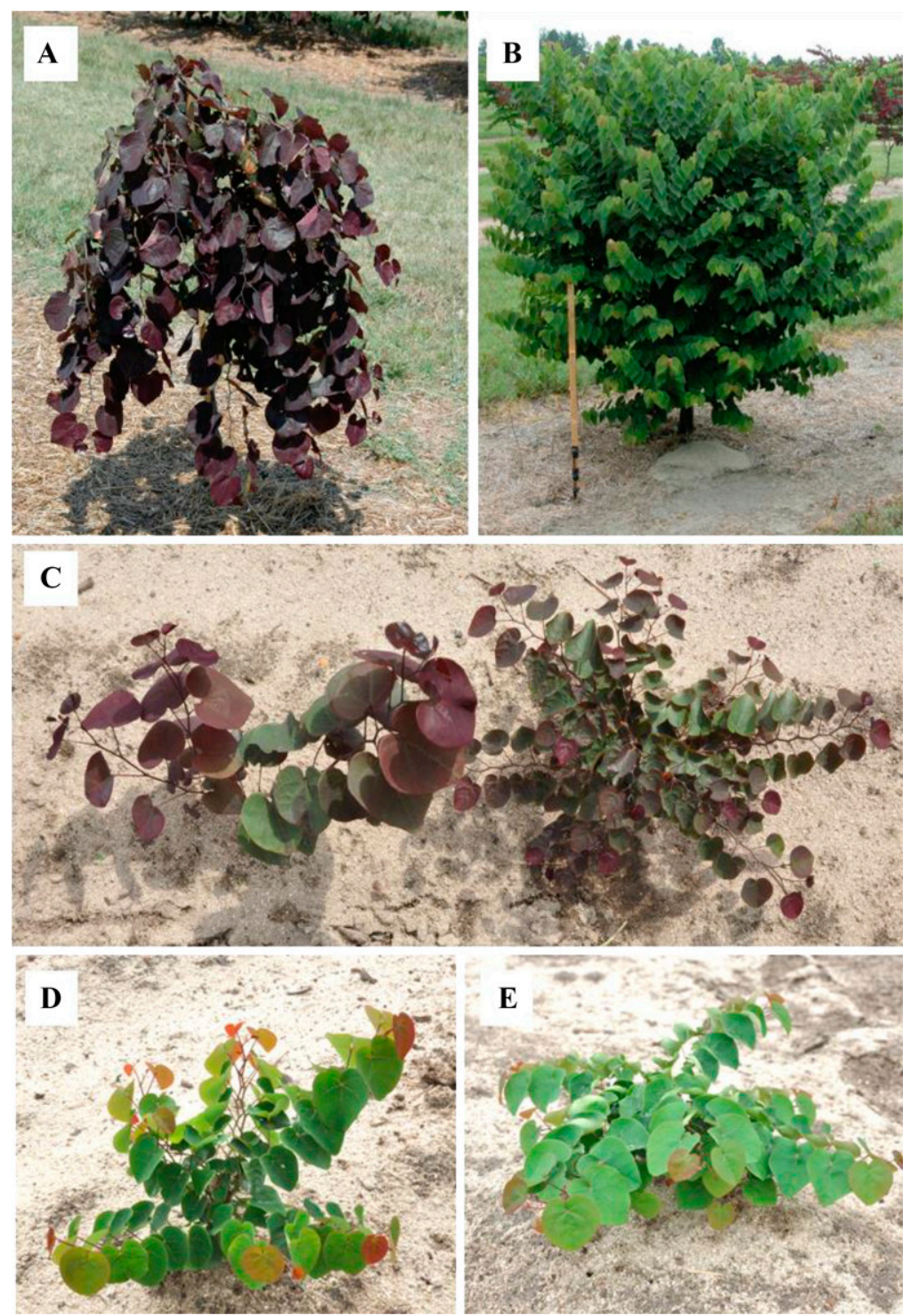

Fig. 1. Morphologies of parental cultivars of Cercis canadensis and their segregated $F_{2}$ progenies. (A) 'Ruby Falls', a noncompact, purple-leaved, weeping cultivar. (B) 'Ace of Hearts', a compact, green-leaved, nonweeping cultivar. $(\mathbf{C})$ Left: a noncompact, purple-leaved, nonweeping $\mathrm{F}_{2}$ plant. Right: a compact, purple-leaved, nonweeping $\mathrm{F}_{2}$ plant. (D) A compact, green-leaved, nonweeping $\mathrm{F}_{2}$ plant. (E) A compact, green-leaved, weeping $\mathrm{F}_{2}$ plant.

stratified as described previously, and sown in Jan. 2018. Seedlings were grown in the greenhouse in individual pots to a height of $\approx 15 \mathrm{~cm}$ before being transplanted into the field plots in May 2018. Trees were evaluated for leaf color, weeping/nonweeping, and compact/noncompact characters in Sept. 2018 (Fig. 1).

Phenotyping. Phenotyping methods for leaf color and weeping/nonweeping characters were applied on 5- to 10-month-old plants as described by Roberts et al. (2015). Phenotyping of compact growth was conducted on 10month-old plants. Plants showing compact growth had demonstrably smaller leaves, enhanced branching, shorter internodes, and reduced height compared with noncompact plants (Fig. 1C). Phenotypes of the three traits were readily identified, and no intermediate phenotypes were observed.

Statistical analysis. Each plant in the $\mathrm{F}_{2}$, $\mathrm{BC}_{1 \mathrm{P} 1}$, and $\mathrm{BC}_{1 \mathrm{P} 2}$ families was phenotyped,

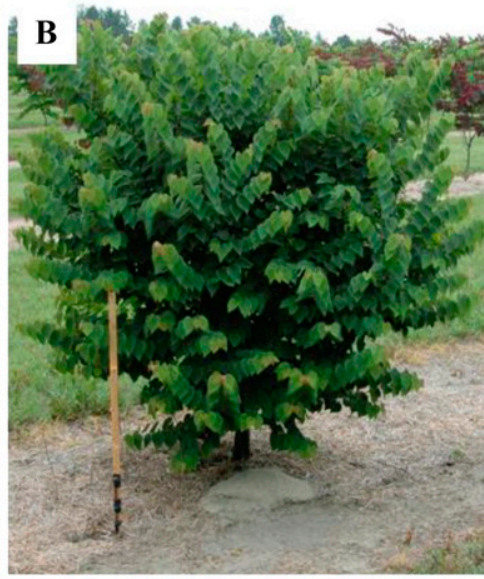

segregation was observed. Odds ratio independence tests between each pair of the three traits were tested to assess the potential linkage between any two genes. The 9:3:3:1 ratio of each of the two traits was further tested by a $\chi^{2}$ goodness-of-fit test with a threshold of $P>$ 0.05 .

\section{Results and Discussion}

Inheritances of the three traits. Segregation results indicated that the three traits are all controlled by single recessive genes (Tables 1-3). All $27 \mathrm{~F}_{1}$ offspring of 'Ruby Falls' $\times$ 'Ace of Hearts' were noncompact, greenleaved, and nonweeping. Segregation data of the three traits characterized by noncompact/ compact (Table 1), green/purple leaf (Table 2), and nonweeping/weeping (Table 3 ) are shown.

Data for the compact trait (Table 1) in the $F_{2}$ family fit the expected 3:1 ratio based on segregation of a single recessive gene ( $P$ value $=0.053>0.05)$. The BCIPI family segregation also fit the expected 1:1 ratio based on control by a single recessive gene $(P$ value $=$ $0.36>0.05)$. Although we accepted the single recessive gene model, the $P$ value of the $\mathrm{F}_{2}$ family was borderline significant. The observed number of compact plants in the $\mathrm{F}_{2}$ and $\mathrm{BC}_{1 \mathrm{P} 1}$ families was slightly less than expected. This phenomenon could be explained by the possibility of slightly reduced fitness and survival of compact progeny during germination or early seedling growth. We propose that 'Ace of Hearts' has a genotype cplcpl (compact) and 'Ruby Falls' has a genotype $C P 1 C P 1$ (noncompact).

For the green/purple leaf trait (Table 2), all $\mathrm{F}_{1}$ progeny were green-leaved, consistent with a single recessive gene model. The segregation ratio of the $F_{2}$ families followed the expected 3:1 segregation ratio expected of a single recessive gene $(P$ value $=0.92>0.05)$. In the $572 \mathrm{~F}_{2}$ progeny, 142 plants were purple-leaved, almost the same as the expected 143 plants. The segregation ratio of the $\mathrm{BC}_{1 \mathrm{P} 1}$ fit the expected 1:1 segregation ratio expected for the single recessive gene model $(P$ value $=$ $1>0.05)$. In the $42 \mathrm{BC}_{1 \mathrm{P} 1}$ progeny, 21 plants were purple-leaved, and 21 were greenleaved. All $\mathrm{BC}_{1 \mathrm{P} 2}$ progeny were expected to be green-leaved; however, five unexpected purple-leaved plants were observed among the $76 \mathrm{BC}_{1 \mathrm{P} 2}$ plants. Without considering the five unexpected purple-leaved plants, all segregation ratios of $\mathrm{F}_{1}, \mathrm{~F}_{2}, \mathrm{BC}_{1 \mathrm{P} 1}$, and $\mathrm{BC}_{1 \mathrm{P} 2}$

Table 1. Segregation ratios and tests for goodness of fit for compact growth habit in $\mathrm{F}_{1}, \mathrm{~F}_{2}$, and backcross families derived from hybridization of Cercis canadensis 'Ruby Falls' (noncompact) $\times$ 'Ace of Hearts' (compact)

\begin{tabular}{|c|c|c|c|c|c|c|}
\hline \multirow[b]{2}{*}{ Cross } & \multirow[b]{2}{*}{ Family } & \multicolumn{2}{|c|}{ Phenotypes } & \multirow[b]{2}{*}{ Test ratio ${ }^{z}$} & \multirow[b]{2}{*}{$\chi^{2}(\mathrm{df}=1)$} & \multirow[b]{2}{*}{$P$ value } \\
\hline & & Noncompact & Compact & & & \\
\hline Ruby Falls $\times$ Ace of Hearts & $\mathrm{F}_{1}$ & 27 & 0 & & & \\
\hline Ruby Falls $\times$ Ace of Hearts & $\mathrm{F}_{2}$ & 449 & 123 & $3: 1$ & 3.73 & 0.053 \\
\hline $\begin{array}{l}\text { Ruby Falls } \times(\text { Ruby Falls } \times \\
\text { Ace of Hearts })\end{array}$ & $\mathrm{BC}_{1 \mathrm{P} 1}$ & 42 & 0 & & & \\
\hline $\begin{array}{l}\text { (Ruby Falls } \times \text { Ace of Hearts }) \times \\
\text { Ace of Hearts }\end{array}$ & $\mathrm{BC}_{1 \mathrm{P} 2}$ & 42 & 34 & $1: 1$ & 0.84 & 0.359 \\
\hline
\end{tabular}

${ }^{\mathrm{z}}$ Single recessive gene test ratio. 
Table 2. Segregation ratios and tests for goodness of fit for leaf color in $\mathrm{F}_{1}, \mathrm{~F}_{2}$, and backcross families derived from hybridization of Cercis canadensis 'Ruby Falls' (purple leaf) × 'Ace of Hearts' (green leaf).

\begin{tabular}{|c|c|c|c|c|c|c|}
\hline \multirow[b]{2}{*}{ Cross } & \multirow[b]{2}{*}{ Family } & \multicolumn{2}{|c|}{ Phenotypes } & \multirow[b]{2}{*}{ Test ratio ${ }^{z}$} & \multirow[b]{2}{*}{$\chi^{2}(\mathrm{df}=1)$} & \multirow[b]{2}{*}{$P$ value } \\
\hline & & Green & Purple & & & \\
\hline Ruby Falls $\times$ Ace of Hearts & $\mathrm{F}_{1}$ & 27 & 0 & & & \\
\hline Ruby Falls $\times$ Ace of Hearts & $\mathrm{F}_{2}$ & 430 & 142 & $3: 1$ & 0.009324 & 0.9231 \\
\hline $\begin{array}{l}\text { Ruby Falls } \times(\text { Ruby Falls } \times \\
\text { Ace of Hearts })\end{array}$ & $\mathrm{BC}_{1 \mathrm{P} 1}$ & 21 & 21 & $1: 1$ & 0.00 & 1.0000 \\
\hline $\begin{array}{l}\text { (Ruby Falls } \times \text { Ace of Hearts) } \times \\
\text { Ace of Hearts }\end{array}$ & $\mathrm{BC}_{1 \mathrm{P} 2}$ & 71 & $5^{y}$ & & & \\
\hline
\end{tabular}

${ }^{\mathrm{z}}$ Single recessive gene test ratio.

${ }^{\mathrm{y}}$ Unexplainable phenotype perhaps caused by occasional self-pollination.

Table 3. Segregation ratios and tests for goodness of fit for weeping in $\mathrm{F}_{1}, \mathrm{~F}_{2}$, and backcross families derived from hybridization of Cercis canadensis 'Ruby Falls' (weeping) $\times$ 'Ace of Hearts' (nonweeping).

\begin{tabular}{lccccccr}
\hline & \multicolumn{4}{c}{ Genotypes } & & & \\
\cline { 3 - 4 } Cross & Family & Nonweeping & Weeping & Test ratio & $\chi^{2}(\mathrm{df}=1)$ & $P$ value \\
\hline Ruby Falls $\times$ Ace of Hearts & $\mathrm{F}_{1}$ & 27 & 0 & & & \\
Ruby Falls $\times$ Ace of Hearts & $\mathrm{F}_{2}$ & 432 & 140 & $3: 1$ & 0.0839 & 0.772 \\
$\begin{array}{l}\text { Ruby Falls } \times \text { (Ruby Falls } \times \\
\quad \text { Ace of Hearts) }\end{array}$ & $\mathrm{BC}_{1 \mathrm{P} 1}$ & 27 & 15 & $1: 1$ & 3.4286 & 0.064 \\
$\begin{array}{l}\text { Ruby Falls } \times \text { Ace of Hearts) } \\
\quad \text { Ace of Hearts }\end{array}$ & $\mathrm{BC}_{1 \mathrm{P} 2}$ & 76 & 0 & & & \\
\hline
\end{tabular}

${ }^{\mathrm{z}}$ Single recessive gene test ratio.

Table 4. Independence test analysis between each pair of the three genes, compact, weeping, and purple leaf, in the $\mathrm{F}_{2}$ population derived from hybridization of Cercis canadensis 'Ruby Falls' (purple leaf/normal growth/weeping) $\times$ 'Ace of Hearts' (green leaf/compact/nonweeping).

\begin{tabular}{llcccc}
\hline Pairs of traits & Phenotype & $\begin{array}{c}\text { Plant numbers } \\
\text { of each phenotype }\end{array}$ & $\begin{array}{c}P \text { value } \\
\text { of OIT }\end{array}$ & $\chi^{2}(\mathrm{df}=3)^{\mathrm{y}}$ & $P$ value \\
\hline Compact/weeping & NS:CS:NW:CW & $337: 95: 112: 28$ & 0.74 & 4.01 & 0.26 \\
Compact/purple & NG:CG:NP:CP & $349: 81: 100: 42^{\mathrm{x}}$ & $0.01^{\mathrm{x}}$ & 10.32 & $0.02^{\mathrm{x}}$ \\
Purple/weeping & GN:PN:GW:PW & $326: 106: 104: 36$ & 0.87 & 0.170 & 0.98 \\
\hline
\end{tabular}

${ }^{\mathrm{Z}}$ OIT refers to odd independence test.

${ }^{\mathrm{y}}$ Expected ratio, 9:3:3:1, based on two independent single recessive genes. Expected numbers are 321:107:107:36.

${ }^{\mathrm{x}}$ Unexplainable excess of nonparental-type double recessive.

$\mathrm{N}=$ noncompact, $\mathrm{C}=$ compact, $\mathrm{S}=$ nonweeping, $\mathrm{W}=$ weeping, $\mathrm{G}=$ green leaf, $\mathrm{P}=$ purple leaf.

families followed the single recessive gene hypothesis. The purple leaf gene from the same ancestor that has been reported previously is controlled by a single recessive gene pll (Roberts et al., 2015), and our results confirmed the single recessive gene 3:1 segregation. The five unexpected purple-leaved plants in the $\mathrm{BC}_{1 \mathrm{P} 2}$ family can be explained by occasional self-pollination or pollen contamination.

In this research, phenotypes of $F_{1}$ and $\mathrm{BC}_{1 \mathrm{P} 2}$ progeny were all nonweeping, consistent with the single recessive gene model (Table 3). The $\mathrm{F}_{2}$ and $\mathrm{BC}_{1 \mathrm{P} 1}$ families fit the expected $3: 1(P$ value $=0.77>0.05)$ and $1: 1$ $(P$ value $=0.06>0.05)$ segregation ratios, respectively, again consistent with the single recessive gene model. Like the compact trait, the observed number of weeping plants in the $\mathrm{F}_{2}$ and $\mathrm{BC}_{1} \mathrm{P}_{1}$ families was slightly lower than expected, which could be explained by reduced survival of weeping progeny in seed or during early seedling growth. Segregation ratios of the weeping trait in the $\mathrm{F}_{1}, \mathrm{~F}_{2}, \mathrm{BC}_{1 \mathrm{P} 1}$, and $\mathrm{BC}_{1 \mathrm{P} 2}$ families are consistent with the earlier report that the weeping trait is controlled by a single recessive gene (Roberts et al., 2015).
Linkage of the three traits. Results of plant numbers and the odds ratio independence tests between trait comparisons are listed in Table 4. Cosegregation of compact/weeping and purple/weeping genes passed the odd independence tests, and there was no significant deviation between the observed segregation numbers and the expected 9:3:3:1 segregation ratio, suggesting no linkage (Table 4). However, cosegregation of the compact and purple leaf traits deviated significantly from the expected 9:3:3:1 ratio $(P$ value $=0.02<0.05)$; this deviation from the expected 9:3:3:1 ratio cannot be explained as due to linkage. In the present research, the two parental cultivars were Ruby Falls (noncompact/purple leaf) and Ace of Hearts (compact/green leaf), with the genes in the repulsion phase. One would expect that deviation due to linkage would result in greater numbers of parental combinations than expected; however, increased nonparental type and reduced parental type phenotypes were observed, arguing against linkage. Thus, our data for testing linkage between these two genes is inconclusive, and further studies are required to resolve this inconsistency.
Like many woody ornamental plants, redbud has a longer generation time than most herbaceous species, thus breeding and selection can be time-consuming and costly. The results of this study can be useful for future redbud breeding efforts, especially in programs focusing on the development of compact cultivars, by allowing the appropriate breeding strategies and population sizes to be determined. Future molecular studies on redbud can confirm the results of this study, and perhaps resolve the inconclusive results of linkage between the compact and purple leaf genes as described in this study. Whole genome sequence studies potentially would allow the identification of the exact gene sequences and locations of these three traits.

\section{Conclusion}

This study is the first to report that the compact trait derived from 'Ace of Hearts' is controlled by a single recessive gene, designated $c p 1$. Furthermore, our study confirms prior research that single recessive genes control both purple leaves ( tecture (wplwpl). Linkage analysis revealed no evidence of linkage among these three traits.

\section{Literature Cited}

Banner, V.A. and W.I. Stein. 2008. Cercis L. Redbud, p. 374-379. In: F.T. Bonner, R.P. Karrfalt, and R.G. Nisley (eds.). The woody plant seed manual. Forest Service, USDA.

Dirr, M.A. 2009. Manual of woody landscape plants: Their identification, ornamental characteristics, culture, propagation and uses. 6th ed. Stipes Publishing Co., Champaign, IL.

Fantz, P.R. and P. Woody. 2005. 'Ace of Hearts' and 'Little Woody' redbuds. HortScience 40(7): 2209-2210, https://doi.org/21273/HORTSCI.40. 7.2209.

Kidwell-Slak, D.L. and M.R. Pooler. 2018. A checklist of Cercis (redbud) cultivars. HortScience 53(2):148-152, https://doi.org/10.21273/ HORTSCI12564-17.

Raulston, J.C. 1990. Redbud. Amer. Nurseryman 171(5):39-51.

Roberts, D.J., D.J. Werner, P.A. Wadl, and R.N. Trigiano. 2015. Inheritance and allelism of morphological traits in eastern redbud (Cercis canadensis L.). Hort. Res. 2(1):1-11, https:// doi.org/10.1038/hortres.2015.49.

U.S. Department of Agriculture, NASS. 2020 Census of horticultural specialties for 2019. 8 Dec. 2020. <https://www.nass.usda.gov/ Publications/AgCensus/2017/Online_Resources/ Census_of_Horticulture_Specialties/hortic_1_ 0020_0021.pdf >.

U.S. Department of Agriculture, NASS. 2015. Census of horticultural specialties for 2014. 24 Jan. 2018. <https://www.agcensus.usda.gov/ Publications/2012/Online_Resources/Census of_Horticulture_Specialties/HORTIC.pdf $>$.

U.S. Department of Agriculture, NASS. 2009. Census of horticultural specialties for 2007. <https:// www.nass.usda.gov/Publications/AgCensus/ 2007/Online_Highlights/Census_of_Horticulture_ Specialties/hortic_1_020_021.pdf>

Werner, D.J. and L.K. Snelling. 2010. 'Ruby Falls' and 'Merlot' redbuds. HortScience 45(1):146147, https://doi.org/10.21273/HORTSCI.45.1. 146. 